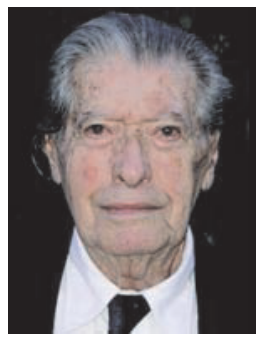

\title{
Walter Lowen
}

\section{MBBS, FRACR}

WALTER LOWEN was born in Vienna on 10 March 1916 and spent his childhood in Lwow, Poland. A national junior table tennis champion, Walter contributed to Poland's bronze medal at the Swaythling Cup world championships in London in 1935. Religious persecution in Europe spurred his migration to Australia in July 1939, a few months before he was due to complete his medical degree at the University of Lwow. In 1940, Walter was accepted into medicine at the University of Melbourne and, in 1941, he married Sima, whom he had met en route to Australia. Walter still pursued table tennis, winning the Australian singles title in 1948 as well as many state singles titles. In 2000, he was inducted into the Table Tennis Victoria Hall of Fame.

Walter graduated in 1945 and undertook his residency at Launceston General Hospital. In 1948, he returned to Melbourne, where he practised as a general practitioner in Reservoir and Ashburton. In 1958, he moved to The Alfred Hospital, Melbourne, where he trained in radiology and, in 1961, he gained Fellowship of the Royal Australasian College of Radiologists. He then developed his diagnostic expertise at the Melbourne Radiology Clinic in female infertility, obstetrics, and thoracic and renal radiology. During this time, he published papers on medullary sponge kidney disease, cavitating pulmonary metastases and radionuclide placental localisation. Walter's obstetric and gynaecological imaging expertise led to his appointment as Director of Radiology at Royal Women's Hospital, Melbourne, between 1962 and 1975. From 1976 until his retirement in 1994, he continued sessional work at Royal Southern Memorial Hospital, Bairnsdale Regional Hospital and Preston and Northcote Community Hospital.

After he retired from medicine, Walter concentrated on his family and competitive bridge. As a Grand Master, he helped Victoria win the open teams event at the Australian National Bridge Championships in 1972. Walter remained intellectually sharp until he died peacefully, aged 94, in Melbourne on 11 January 2011, survived by Sima and their three children Richard, Mark and Norma. Walter was inspirational and generous to many, and is remembered with affection as a gentle giant.

Richard J Lowen, Mark Lowen, Norma Gilbert doi:10.5694/mjall.11447 